\title{
Menjaga Kesehatan Mental Perspektif Al-Qur'an dan Hadits
}

\author{
Oleh: \\ Ikhwan Fuad \\ (Sekolah Tinggi Ilmu Tarbiyah Muhammadiyah Pacitan)
}

\begin{abstract}
Abstrak
Artikel ini menguraikan tentang teori-teori psikologi dalam Al-Qur'an dan Sunnah tentang cara menjaga kesehatan mental. Sebagai sumber dasar Islam, AlQur'an dan Hadis mengandung banyak informasi dan pengetahuan, termasuk masalah kesehatan mental di tengah kekhawatiran dunia psikologi saat ini. Dengan pendekatan penulis normatif-teologis mencoba menggali teks yang membahas topik ini dan menjelaskan teori-teori. Penulis sampai pada kesimpulan bahwa 1) menjaga kesehatan mental dalam perspektif Al-Qur'an dan Sunnah berdasarkan wasathiyah gagasan (moderasi) dalam memenuhi kebutuhan material dan, 2) metode spiritual Al-Qur'an dan Hadis di mewujudkan kesehatan mental, antara lain dengan memperkuat dimensi spiritual, pengendalian motivasi biologi dan metode belajar yang diperlukan untuk kesehatan mental. Pencapaian metode ini dapat dilihat dari kehidupan nabi dan sahabata dari hubungan dengan Allah, dengan dirinya sendiri, hubungan dengan orang lain, dan alam semesta.
\end{abstract}

Kata Kunci: Kesehatan Mental, Alquran dan Hadis, Psikologi

\section{Abstrak}

This article elaborates on theories of psychology in the Qur'an and Sunnah on how to maintain mental health. As the basic source of Islam, the Qur'an and the Hadith contains much information and knowledge, including mental health problems amid concern the world of psychology today. With the approach of Normative- 
theological author tried to dig texts that discuss these topics and explain its theories. The author came to the conclusion that 1) maintaining of mental health in Qur'an and Sunnah perspective based on the notion wasathiyah (moderation) in fulfilling the needs of the material and the spiritual, 2) method of the Qur'an and Hadith in realizing mental health, among others by strengthening the spiritual dimension, control of biological motivations and methods learned are necessary for mental health. Achievement of these methods can be seen from the life of the prophet and the sahabata of the relationship with God, with himself, his relationships with others, and the universe.

Keyword: Mental Health, Qur'an and Hadith, Psychology.

\section{Pendahuluan}

Kehidupan dewasa ini telah berada pada era yang disebut dengan globalisasi, yaitu kondisi dimana manusia hidup tanpa sekat dan batas-batas wilayah dan dapat berhubungan satu sama lain untuk bertukar informasi di mana pun dan kapan pun. Proses globalisasi yang ditandai dengan kemajuan teknologi informasi yang pesat berdampak pada segala aspek kehidupan terutama pada budaya masyarakat dan nilai-nilai sosial yang berlaku di dalamnya. Persaingan dunia industri barang dan jasa ternyata berimplikasi pada aspek-aspek kejiwaan masyarakat berupa agresifitas, emosi yang tidak terkendali, ketidakmatangan kepribadian, depresi karena tekanan kehidupan, tingkat kecurigaan yang meningkat, dan persaingan yang tidak sehat hingga menyebabkan tingginya angka bunuh diri (Febriana, 2011).

Kesehatan mental dan masalah psikososial merupakan masalah serius dan membutuhkan perhatian. Sebuah fakta menunjukkan, lebih dari separoh tempat tidur di semua rumah sakit di Amerika Serikat terisi oleh pasien-pasien gangguan mental, dan untuk mereka dikeluarkan dana jutaan dolar pertahunnya (Fromm, 1995). Kasus ini tidak menutup kemungkinan juga terjadi di Indonesia dimana banyak individu secara lahiriyah tampak sehat, terpenuhi segala macam kebutuhan material, akan tetapi jika ditelusuri lebih 
jauh mungkin sebagian besar individu yang hidup di tengahtengah masyarakat tersebut menderita penyakit mental yang cukup parah, sehingga pada stadium berikutnya akan mengerogoti ketahanan fisik. Gejala gangguan mental sangat berpengaruh pada produktivitas seseorang karena sehat tidaknya seseorang berkaitan dengan kemampuan adaptasi terhadap problematika yang ada. Orang yang sehat mentalnya akan mampu menghadapi kenyataan hidup dengan perasaan senang, tentram dan bahagia sehingga kepribadinya menjadi mantap dan siap berkarya bagi komunitasnya.

Bidang kesehatan mental saat ini menjadi satu bidang yang paling menarik di antara bidang-bidang psikologi, baik di kalangan ilmuwan maupun orang awam. Sebab, untuk mencapai tingkat yang sesuai dengan kesehatan mental itulah dambaan setiap individu. Akan tetapi dalam mengkaji masalah kesehatan mental, terkadang ilmuwan dan psikolog hanya memperhatikan dimensi biologis dan dimensi sosial sedikit mengabaikan dimensi spiritual. Luputnya perhatian kepada dimensi spiritual dari pengamatan psikolog modern menurut penulis akan menyebabkan pemahaman akan kepribadian manusia menjadi kurang sempurna, apalagi di Indonesia yang masyarakatnya mayoritas adalah muslim. Dalam pandangan Islam tentu memahami manusia dengan benar tidak hanya dengan memperhatikan dimensi biologisnya atau keadaan sosial dan budaya yang menyertainya, akan tetapi menuntut adanya integrasi seluruh faktor pembentuk kepribadian termasuk di dalamnya dimensi spritual.

Al-Qur'an dan Al-Hadits sebagai sumber utama ajaran Islam memberikan petunjuk dan bimbingan bagi manusia dalam menjaga fitrahnya untuk meraih kebahagiaan yang hakiki. Al-Quran memperkenalkan istilah jiwa yang tenang (an-nafsu al-muthmainnah), sementara Al-hadits menyebut kata al-fithrah, keduanya adalah syarat bagi kesehatan mental yang harus dimiliki seorang muslim. Hidup dengan jiwa yang tenang harus berdasarkan fitrah yang telah diberikan oleh Allah Subhanahu Wata'ala yaitu akidah tauhiid. Tentu saja fitrah ini membutuhkan sesuatu yang memeliharanya dan 
membuatnya tumbuh menjadi lebih baik. Sesuatu yang bisa menjaga dan membuat fitrah menjadi lebih baik tidak lain adalah syariat agama yang diturunkan oleh Allah Ta'ala (Taimiyah, tth).

Berdasarkan uraian di atas, penulis tertarik untuk mengelaborasi lebih lanjut tentang hakikat kesehatan mental dan bagaimana metode Al-Qur'an dan Al-Hadits dalam merealisasikan kesehatan mental dan indikator-indikatornya kesehatan mental tersebut. Dengan pendekatan normatifteologis, penulis ingin menggali teori-teori psikologi dari alQur'an dan al hadits tentang bagaimana menjaga kesehatan mental. Penulis memandang perlu dan penting untuk menghadirkannya mengingat teori psikologi yang berkembang didominasi oleh teori-teori psikologi barat yang bersumber dari filsafat materlisme-behaviorisme.

\section{Pembahasan}

\section{Hakikat Kesehatan Mental}

Badan kesehatan dunia (WHO) mendefinisikan: "mental health is defined as a state of well-being in which every individual realizes his or her own potential, can cope with the normal stresses of life, can work productively and fruitfully, and is able to make a contribution to her or his community" (Kesehatan mental didefinisikan sebagai keadaan sejahtera di mana setiap individu menyadari potensi dirinya sendiri, (sehingga) dapat mengatasi tekanan yang normal dalam kehidupan, dapat bekerja secara produktif dan baik, dan mampu memberikan kontribusi untuk komunitasnya) (http://www.who.int/features/factfiles/mental_health/en/).

Frank L.K. sebagaimana dikutip oleh Notosudirdjo dan Latipun (2005) mengemukakan bahwa orang yang sehat mentalnya adalah orang yang terus tumbuh berkembang dan matang dalam hidupnya, menerima tanggung jawab, menemukan penyesuaian (tanpa membayar terlalu tinggi biayanya sendiri atau oleh masyarakat) dalam berpartisipasi dalam memelihara aturan sosial dan tindakan dalam budayanya. Sementara menurut Musthafa Fahmi (1977), kesehatan mental mempunyai pengertian dan batasan yang banyak. la mengemukakan dua pengertian; Pengertian 
pertama, mengatakan kesehatan jiwal adalah bebas dari gejala-gejala penyakit jiwa dan gangguan kejiwaan. Pengertian ini banyak dipakai dalam lapangan kedokteran jiwa (psikiatri). Pengertian kedua dari kesehatan jiwa adalah dengan cara aktif, luas, lengkap tidak terbatas; ia berhubungan dengan kemampuan orang untuk menyesuaikan diri dengan dirinya sendiri dan dengan masyarakat lingkungannya, hal itu membawanya kepada kehidupan yang sunyi dari kegoncangan, penuh vitalitas. Dia dapat menerima dirinya dan tidak terdapat padanya tanda-tanda yang menunjukkan tidak keserasian sosial, dia juga tidak melakukan hal-hal yang tidak wajar, akan tetapi ia berkelakuan wajar yang menunjukkan kestabilan jiwa, emosi dan pikiran dalam berbagai lapangan dan di bawah pengaruh semua keadaan.

Zakiah Daradjat (1983) mengemukakan lima buah rumusan kesehatan jiwa yang lazim dianut para ahli. Kelima rumusan itu disusun mulai dari rumusan- rumusan yang khusus sampai dengan yang lebih umum, sehingga dari urutan itu tergambar bahwa rumusan yang terakhir seakan-akan mencakup rumusan-rumusan sebelumnya, antara lain:

1. Kesehatan mental adalah terhindarnya orang dari gejala gangguan jiwa (neurose) dan dari gejala-gejala penyakit jiwa (psichose). Definisi ini banyak dianut di kalangan psikiatri (kedokteran jiwa) yang memandang manusia dari sudut sehat atau sakitnya.

2. Kesehatan mental adalah kemampuan untuk menyesuaikan diri dengan dirinya sendiri, dengan orang lain dan masyarakat serta lingkungan tempat ia hidup. Definisi ini tampaknya lebih luas dan lebih umum daripada definisi yang pertama, karena dihubungkan dengan kehidupan sosial secara menyeluruh. Kemampuan menyesuaikan diri diharapkan akan menimbulkan ketenteraman dan kebahagiaan hidup.

3. Kesehatan mental adalah terwujudnya keharmonisan yang sungguh-sungguh antara fungsi-fungsi jiwa, serta mempunyai kesanggupan untuk menghadapi problemaproblema yang biasa terjadi, serta terhindar dari kegelisahan dan pertentangan batin (konflik). Definisi ini menunjukkan bahwa fungsi-fungsi jiwa seperti pikiran, 
perasaan, sikap, pandangan dan keyakinan harus saling menunjang dan bekerja sama sehingga menciptakan keharmonisan hidup, yang menjauhkan orang dari sifat ragu-ragu dan bimbang, serta terhindar dari rasa gelisah dan konflik batin.

4. Kesehatan mental adalah pengetahuan dan perbuatan yang bertujuan untuk mengembangkan dan memanfaatkan potensi, bakat dan pembawaan yang ada semaksimal mungkin, sehingga membawa kepada kebahagiaan diri dan orang lain, serta terhindar dari gangguan dan penyakit jiwa.

Dari definisi-definisi di atas dapat dipahami bahwa para psikolog mendefinisikan kesehatan mental dengan definisi yang beragam namun tetap fokus penekanannya pada masalah prilaku manusia. Secara umum mereka mendefiisikan kesehatan mental sebagai sebuah kematangan seseorang pada tingkat emosional dan kematangan secara sosial untuk melakukan upaya-upaya adaptasi dengan dirinya sendiri dan alam sekitar, serta kemampuannya mengemban tanggung jawab kehidupan dan siap menghadapi segala problematikannya. Dengan kesehatan mental seseorang dapat hidup dengan perasaan senang dan bahagia.

Berkaitan dengan ciri dan indikator kesehatan mental, Marie Jahoda sebagaimana dikutip Jaelani (2000) memberikan batasan yang agak luas. Menurutnya, kesehatan mental tidak hanya terbatas pada absennya seseorang dari gangguan kejiwaan dan penyakitnya. Akan tetapi, orang yang sehat mentalnya memiliki ciri-ciri utama sebagai berikut.

1. Sikap kepribadian yang baik terhadap diri sendiri dalam arti dapat mengenal diri sendiri dengan baik.

2. Pertumbuhan, perkembangan, dan perwujudan diri yang baik.

3. Integrasi diri yang meliputi keseimbangan mental, kesatuan pandangan, dan tahan terhadap tekanan- tekanan yang terjadi.

4. Otonomi diri yang mencakup unsur-unsur pengatur kelakuan dari dalam atau kelakuan-kelakuan bebas.

5. Persepsi mengenai realitas, bebas dari penyimpangan kebutuhan, serta memiliki empati dan kepekaan sosial. 
6. Kemampuan untuk menguasai lingkungan dan berintegrasi dengannya secara baik.

Adapun Utsman Najati (2003), seorang pakar psikologi Islam mengutip beberapa pendapat ahli ilmu jiwa tentang indikator-indikator yang menunjukkan bahwa seseorang telah mencapai kesehatan mental yang baik diantaranya pendapat Maslow yang menyatakan bahwa "indikator seseorang telah mencapai kesehatan mental adalah adanya hubungan dirinya dengan beberapa nilai seperti kejujuran seseorang pada dirinya sendiri dan kepada orang lain, memiliki keberanian untuk mengungkapkan kebenaran, bertanggung jawab dalam melalukan sesuatu yang ia kerjakan, berani mengaku siapa dirinya sebenarnya, apa yang dia kehendaki dan ia sukai, serta mau mengakui mana hal-hal yang baik sekalipun tidak berasal darinya, sekaligus mau menerima hal baik tesebut tanpa bermaksud mengadaan pembelaan diri demi merusak hakikat kebenaran yang ada."

Selain pendapat Maslow, Najati (2003) juga mengetengahkan pendapat Muhammad Audah dan Kamal Ibrahim yang mengisyaratkan pentingnya dimensi spiritual dalam memandang kesehatan mental. Indikator-indikator kesehatan mental menurut keduanya harus mencakup dimensi-dimensi kehidupan antara lain:

1. Dimensi Spiritual, terdiri dari keimanan kepada Allah, melakukan ibadah, menerima ketentuan dan takdir Allah, senantiasa merasa dekat dengan Allah, memenuhi kebutuhannya secara halal, dan selalu berdzikir kepada Allah.

2. Dimensi Psikologis, terdiri dari kejujuran, terbebas dari rasa dengki iri, merasa percaya diri, mampu menanggung kegagalan dan rasa gelisah, menjauhi hal-hal yang menyakiti jiwa seperti sifat sombong, menipu, boros, pelit, malas dan pesimis, berpegang kepada prinsip-prinsip syariat, memiliki keseimbangan emosional, lapang dada, mudah menerima kenyataan hidup, mampu mengendalikan, mengekang hawa nafsu, dan tidak terlalu berambisi.

3. Dimensi Sosial, terdiri dari mencintai kedua orang tua, rekan dan anak, membantu orang yang membutuhkan, 
bersikap amanah, berani mengatakan yang benar, bertanggun jawab, dan menjahui hal-hal yang dapat menyakiti orang lain, seperti berbohong, memanipulasi, mencuri, berzina, membunuh, memberikan saksi palsu, memakan harta anak yatim, menfitnah, khianat, dan suka berbuat dzalim.

4. Dimensi Biologis, terdiri dari sehat dari berbagai penyakit, tidak cacat fisik, memperhatikan kesehatan, dan tidak membebani fisik sesuai dengan kemampuannya.

Berdasarkan tolak ukur di atas kiranya dapat digambarkan secara ideal bahwa orang yang benar-benar sehat mentalnya adalah orang yang beriman dan bertaqwa kepada Tuhan Yang Maha Esa serta berusaha secara sadar merealisasikan nilai-nilai agama, sehingga kehidupannya itu dijalaninya sesuai dengan tuntunan agamanya. la pun secara sadar berupaya untuk mengembangkan berbagai potensi dirinya, seperti bakat, kemampuan, sifat, dan kualitas-kualitas pribadi lainnya yang positif. Sejalan dengan itu ia pun berupaya untuk menghambat dan mengurangi kualitaskualitas negatif dirinya, karena sadar bahwa hal itu dapat menjadi sumber berbagai gangguan dan penyakit kejiwaan.

Adapun gangguan atau penyakit jiwa di masyarakat menurut Harawi (1995) antara lain:

1. Fobia, yaitu rasa takut yang tidak rasional dan tidak realistis, yang bersangkutan tahu dan sadar benar akan ketidakrasionalnya dan ketidakbenarannya, namun ia tidak mampu mencegah dan mengendalikan diri dari rasa takut itu.

2. Obsesi, yaitu corak pikiran yang sifatnya terpaku (persistent) dan berulangkali muncul. Yang bersangkutan tahu benar akan kelaianan pikirannya itu, namun ia tidak mampu mengalihkan pikirannya pada masalah lain dan tidak mampu mencegah munculnya pikiran itu yang selalu timbul berulang-ulang.

3. Kompulsi, yaitu suatu pola tindakan atau perbuatan yang diuang-ulang. Yang bersangkutan tahu benar bahwa perbuatan mengulang-ulang itu tidak benar dan tidak rasional, namun yang bersangkutan tidak mampu mencegah perbuatannya sendiri. 
Sementara dalam pandangan psikologi Islam, penyakit mental yang biasa berjangkit pada diri manusia, antara lain:

1. Riya'. Penyakit ini mengandung tipuan, sebab menyatakan sesuatu yang tidak sebenarnya, orang yang berbuat riya' mengatakan atau melakukan perbuatan yang tidak sesuai dengan hakikat yang sebenarnya.

2. Hasad dan dengki, yaitu suatu sikap yang melahirkan sakit hati apabila orang lain mendapat kesenangan dan kemuliaan, dan ingin agar kesenangan dan kemulian itu hilang dari orang tersebut dan beralih kepada dirinya.

3. Rakus, yaitu keinginan yang berlebihan untuk makan.

4. Was-was. Penyakit ini sebagai akibat dari bisikan hati, citacita, dan angan-angan dalam nafsunya dan kelezatan.

5. Berbicara berlebihan. Keinginan berbicara banyak merupakan salah satu kwalitas manusia yang paling merusak. Hal ini dapat mengahantarkan kepada pembicaraan yang tidak berguna dan berbohong. Dan lain sebagainya (Langgulung, 1986).

\section{Metode Al-Qur'an dan Al Hadits dalam Merealisasikan Kesehatan Mental}

Kesehatan mental lahir dari kepribadian yang mantap. Semua indikator kepribadian yang mantap tersebut ada pada kepribadian Rasulullah SAW. Beliau adalah sosok yang mampu menyeimbangkan antara dimensi-dimensi kehidupan yang ada, sehingga Allah memujinya sebagai pribadi yang agung akhlaknya. Allah berfirman: "Dan Sesungguhnya kamu (Muhammad) benar-benar berbudi pekerti yang agung".(QS. Al-Qolam: 4). Rasulullah adalah prototipe ideal untuk annafsu al muthmainnah yang memiliki indikator kesehatan mental level tinggi.

Al-Qur'an dan Sunnah sebagai sumber utama ajaran Islam memiliki metode yang khas dalam merealisasikan kesehatan mental dilengkapi dengan model nyata dari Rasulullah SAW menjadi sebuah panduan lengkap bagi umat Islam dan manusia secara umum. Hal ini berbeda dengan pemikiran psikologi lain yang lebih bersifat teoritis karena tidak disertai model yang merealisasikan teori-teori tersebut. Menurut Quraish Shihab (2003) Islam telah menetapkan 
tujuan pokok kehadirannya untuk memelihara agama, jiwa, akal, jasmani, harta, dan keturunan. Setidaknya tiga dari yang disebut di atas berkaitan dengan kesehatan. Tidak heran jika ditemukan bahwa Islam amat kaya dengan tuntunan kesehatan.

Adapun metode Al-Qur'an dan Al-Hadits dalam merealisasikan kesehatan mental jika disimpulkan dari nashnash yang umum maupun yang khusus tentang kesehatan mental meliputi tiga metode yaitu metode penguatan dimensi spiritual, metode menguasai dimensi biologis dan metode mempelajari hal yang urgen untuk kesehatan mental (Najati, 2003).

\section{Metode Penguatan Dimensi Spiritual}

Untuk memperoleh ketenangan dan ketenraman jiwa yang hakiki, Islam sejak awal mengajak manusia kepada iman dan mentauhidkan Allah. Tujuannya tidak lain agar mereka terbebas dari etika dan tradisi jahiliyah yang mewarnai pikiran mereka dengan kebodohan dan khurafat. Metode ini benarbenar memiliki pengaruh yang sangat besar dalam merubah kepribadian bangsa Arab waktu itu, sehingga mereka menjadi jiwa yang tidak lagi mengkhawatirkan hal-hal yang dahulu sangat mereka cemaskan seperti rasa takut mati, takut miskin, takut terkena musibah, mapun takut kepada sesama manusia. Dengan keimanan dan tauhid mereka benar-benar merasakan keamanan jiwa (Najati, 1987). Hal ini sebagaimana firman Allah: "Orang-orang yang beriman dan tidak mencampuradukkan iman mereka dengan syirik, mereka itulah orangorang yang mendapat rasa aman dan mereka mendapat petunjuk." (QS. Al-An'aam: 82).

Rasulullah SAW mengajak manusia untuk beriman dan mentauhidkan Allah menghabiskan waktu 13 tahun sebelum mengajak mereka untuk melaksanakan syariat. Iman yang tertanam kuat di dalam hati dapat menghadirkan rasa lapang dada, ridha dan bahagia dalam diri sesesorang. Dia akan merasa dalam perlindungan dan penjagaan Allah serta dibimbing hidupnya sehingga membuannya menjadi tenang dan dicintai banyak orang. Allah berfirman:"(yaitu) orangorang yang beriman dan hati mereka menjadi tenteram 
dengan mengingat Allah. Ingatlah, hanya dengan mengingat Allah hati menjadi tenteram." (QS. Ar-Ra'd : 28).

Metode penguatan dimensi spiritual juga dilakukan Nabi dengan membimbing sahabatnya untuk mengarahkan tujuan hidupnya untuk akhirat. Nabi bersabda:

Barang siapa akhirat menjadi tujuan hidupnya, maka Allah akan meletakkan rasa kecukupan di dalam hatinya dan mengumpulkan segala sesuatu yang terserak untuk dirinya. Dia pun akan dihampiri dunia sementara dunia sendiri merupakan sesuatu yang hina. Barang siapa dunia menjadi tujuannya maka Allah akan menjadikan kefakiran berada di depan pelupuk matanya dan menjadikan sesuatu yang telah terkumpul menjadi tercerai-berai dari dirinya. Dia tidak akan dihampiri dunia kecuali hanya yang telah ditakdirkan untuknya. Maka dia tidak akan dijuluki kecuali sebagai seorang yang fakir dan memang akan menjadi fakir. Seorang hamba tidak akan menghadap Allah kecuali Allah akan menjadikan hati orang-orang mukmin tunduk kepadanya dengan rasa cinta dan sayang. Allah lebih cepat darinya untuk melakukan segala sesuatu yang baik. (HR. AtTirmidzi).

Ketika keimanan telah mantap dan tujuan hidup terarah menuju Allah, penguatan dimensi spiritual dilakukan dengan membebankan syariat. Praktik-praktik ibadah seperti shalat, puasa, zakat, haji merupakan upaya pendidikan untuk membentuk kepribadian manusia. Ibadah-ibadah yang dilakukan berfungsi membersihkan jiwa dan mengajarkan sifat-sifat terpuji yang mampu membuatnya bertahan dalam menghadapi kenyataan hidup. Allah memerintahkan orangorang beriman untuk meminta pertolongan kepada-Nya dengan sabar dan salat, sedangkan itu tidak akan mempu dicapai kecuali oleh orang-orang yang khusyu'. (QS. AlBaqarah: 45 dan 153). Orang terbiasa melakukan ibadahibadah yang disyariatkan akan terlatih untuk sabar menanggung beban, mengokohkan tekad menciptakan rasa cinta dan berbuat baik kepada orang lain, serta memupuk spirit untuk melakukan interaksi sosial. Ketika orang-orang yang mengalami tekanan, pengalaman emosional yang buruk, pertarungan bathin yang menyebabkannya menderita 
penyakit jiwa, ibadah-ibadah di dalam Islam dapat berfungsi sebagai media psikoterapi yang mujarab.

\section{a. Psikoterapi Melalui Shalat}

Ritual shalat memiliki pengaruh yang sangat luar biasa untuk terapi rasa galau dan gundah. Dengan mengerjakan shalat secara khusyuk akan menghadirkan rasa tenang, tentram dan damai. Rasulullah SAW senantiasa mengerjakan shalat ketika ditimpa masalah yang membuat dirinya menjadi tegang. Diriwayatkan oleh Hudzaifah RA bahwa ia berkata; “Jika Nabi Shallallahu 'Alaihi Wasallam merasa gundah karena sebuah perkara, maka beliau menunaikan shalat (HR. Abu Dawud) Hal ini tentu mengisyaratkan pentingnya ritual shalat untuk menciptakan rasa tenang dan tentram pada jiwa seseorang.

Allah memerintahkan hambanya untuk meminta pertolongan dengan sabar dan shalat dikarenakan Allah akan menguji mereka dengan sedikit ketakutan, kelaparan, kekurangan harta, jiwa dan kekurang bahan pangan. Allah SWT berfirman: "Wahai orang-orang yang beriman! Mohonlah pertolongan (kepada Allah) dengan sabar dan shalat. Sungguh, Allah beserta orang-orang yang sabar. Dan Firman-Nya: "Dan Kami pasti akan Menguji kamu dengan sedikit ketakutan, kelaparan, kekurangan harta, jiwa, dan buah-buahan. Dan sampaikanlah kabar gembira kepada orang-orang yang sabar" (QS. Al Baqarah: 153 dan 155). Ketika dalam keadaan shock atau ketakutan tubuh dipaksa mengeluarkan reaksi biologis seperti mengeluarkan hormon andrenalin sebagai persiapan untuk menghadapi kondisi tertentu. Hal itu dapat memicu perubahan jiwa dan pikiran karena kondisi susunan syarat terpengaruh dan keadaan kelenjar endokrin yang reaktif (Salim, 2009).

Diantara proses psikoterapi dalam shalat adalah membaca atau mendengarkan ayat-ayat Al-Qur'an sebagai obat yang tidak didapatkan di apotik dan rumah sakit. Ahmad Al-Qadzi, ketua pusat informasi Yayasan Ilmu Kedokteran di Amerika mengemukakan hasil percobaan yang menguji keabsahan bacaan al-Qur'an memiliki pengaruh terhadap kesehatan yaitu 97\% Al-Qur'an memiliki pengaruh. Al-Qur'an 
menurunkan ketegangan urat saraf dengan keefektifan mencapai 65\% dibandingkan dengan bacaan selainnya yang hanya mencapai 35\%. Hal ini tentu sangat baik bagi kesehatan fisik maupun mental dikarenakan sel saraf merupakan bagian terpenting dari otak yang berfungsi sebagai pengendali pikiran, perasaan dan gerakan fisik (Salim, 2009).

Selain manfaat psikoterapi di atas, shalat bermanfaat dalam pembentukan mental seseorang diantaranya mengajari bagaiamana menghargai waktu, disiplin dan sungguh-sungguh dalam melaksanakan aktivitas. Kekuatan spritual juga mampu membangkitkan harapan, memantapkan tujuan, memperkokoh semangat, dan memunculkan kekuatan yang membuat seseorang siap menerima ilmu pengetahuan dan hikmah.

\section{b. Psikoterapi melalui Puasa}

Dalam ibadah puasa terdapat unsur latihan bagi seseorang untuk bersabar menanggung beban berat kehidupan seperti menahan rasa haus dan lapar, menahan marah serta menahan untuk berbuat yang tidak baik. Dalam sudut sosial, ketika seseorang menahan lapar dan dahaga maka ia akan ikut merasakan penderitaan kaum fakir miskin yang sering kali tidak bisa mengkonsumsi makanan. Rasa empati yang timbul akan mendorong seseorang yang berpuasa mengasihi saudaranya yang bernasib kurang baik secara eknomi. Dia akan memberikan pertolongan dan berbuat baik kepada orang-orang yang membutuhkan sehingga hubungan sosialnya menjadi lebih baik. Kepekaan dan tanggung jawab sosial cenderung mendorong seseorang untuk berbagi sehingga ia merasa sebagai anggota masyarakat yang bermanfaat bagi komunitasnya dan akhirnya ia merasa tentram. Inilah yang disebut oleh Jamaluddin Ancok sebagai Hunger Project (Ancok dan Suroso, 1995).

Dari sisi psikis, ibadah puasa berguna untuk mengobati perasaan berdosa dan menghilangkan kegundahan. Rasulullah menyatakan dalam sabdanya: "Barang siapa yang menunaikan puasa ramadhan dilandasi dengna iman dan ikhlas mengharap ridha Allah maka diampuni dosa-dosanya yang telah lalu." (HR. Al-Bukhari, Muslim, Abu Dawud, 
Tirmidzi, An-Nasa'i dan Imam Ahmad). Bahkan beberapa hadits secara spesifik menjelaskan tentang pengampunan dosa tersebut seperti puasa arafah melebur dosa setahun sebelum dan sesudahnya, Asyura melebur dosa setahun sebelumnya, dan sebagainya (Najati, 2003).

\section{c. Psikoterapi Melalui Ibadah Haji}

Ritual ibadah haji seperti thawaf, wujuf, sa'i dan melempar jumrah merupakan kegiatan yang sarat makna. Thawaf dan wukuf di arafah menjadi media meditasi untuk merenungi perbuatan masa lampau yang menjauhkan diri dari Allah swt dan memahami lebih dalam hakikat tujuan hidup. Perjalanan Shafa dan Marwah bermakna perjuangan spiritualitas diri untuk bertarung melawan hawa nafsu. Melempar Jumrah 'Aqabah mengisyaratkan melempar semua sifat kejahiliahan seperti kemunafikan, kedustaan dan keduniawian. Hal itu adalah gambaran dari kisah perjuangan Nabi Ibrahim yang mengorbankan apa yang dicintai untuk meraih ridha dan kasih sayang-Nya (Suharto, 2002).

Menunaikan ibadah haji dapat melatih kesabaran, melatih jiwa untuk berjuang, serta mengontrol syahwat dan hawa nafsu. Ibadah haji menjadi terapi atas kesombongan, arogansi, dan berbangga diri sebab dalam praktek ibadah haji kedudukan semua manusia sama. Permohonan ampunan dan ditambah suasana yang bergemuruh penuh lantunan Ilahi membuat suasana ibadah haji sarat dengan nilai spiritualitas yang dapat mengobarkan rasa semangat yang tinggi untuk meraih ketenangan (Najati, 2003). Selain itu, Nabi menghabarkan bahwa ibadah haji dapat melebur dosa melalui sabdanya: "Antara umrah sampai umrah berikutnya dapat melebur dosa-dosa yang ada di antara keduannya, dan haji mabrur tidak ada balasannya kecuali surga (HR. Al Bukhari dan Muslim).

\section{d. Psikoterapi Melalui Dzikir dan Doa}

Dzikir dan doa adalah ibadah yang utama dalam Islam bahkan menjadi intinya. Dzikir yang dilakukan akan membuat hati dan jiwa menjadi tenang. Rasulullah mengajari para sahabat untuk senantiasa berdzikir dan berdoa untuk 
memperkuat hubungannya dengan Allah, dan mendekatkan diri kepada-Nya setiap saaat. Dengan berdoa seorang hamba dapat mengungkapkan isi hatinya dan mencurahkan kegundahannya, mengadu kepada sang pencipta. Hal ini akan memberi efek ketenangan disebabkan keyakinan bahwa Allah akan membantunya keluar dari permasalahan. Allah berfirman: "Dan Tuhan-mu Berfirman, "Berdoalah kepada-Ku, niscaya akan Aku Perkenankan bagimu. Sesungguhnya orang orang yang sombong tidak mau menyembah-Ku akan masuk neraka Jahannam dalam keadaan hina dina." (QS. Al Ghafir: 60).

Dari uraian diatas dapat disimpulkan bahwa metode penguatan dimensi spiritual dilakukan melalui tiga tahapan yaitu menanamkan iman dan tauhid, mengarahkan tujuan hidup dan melaksankan ibadah-ibadah yang disyariatkan dalam agama. Jika tahapan-tahapan ini mampu dilaksanakan dengan baik maka kepribadian yang mantap akan terbentuk dan pada akhirnya mengantarkan seseorang kepada kebahagiaan dan kesehatan mental bahkan mampu mengembangkan potensi diri secara optimal.

\section{Metode Pengendalian Motivasi Biologis}

Besarnya perhatian Islam kepada penguatan dimensi spiritual, bukan berarti mengabaikan dimensi biologis. Islam tidak cara hidup monastik (kerahiban) yang menghalangi seseorang untuk melampiaskan kebutuhan biologisnya. Islam memiliki ajaran yang moderat (al-wasathiyah) menganjurkan pemeluknya untuk memilih jalan tengah dalam memenuhi kebuhan spritual dan material dalam dirinya. Pengontrolan dimensi biologis sangat ditekankan demi menjaga kesehatan fisik maupun mental.

Adanya motivasi-motivasi biologis dalam diri seseorang dipandang Islam sebagai sebuah fithrah yang tidak boleh diputus. Yang diinginkan Islam dalam pengendalian motivasi biologis adalah agar seseorang mampu mengatur dengan baik pemuasan motivasinya dengan tetap memperhatikan kemashlahatan individu dan sosial. Al-Quran dan Al-Hadits mengajarkan cara mengatur pemuasan motivasi manusia yang bersifat fithrah dengan berpegang kepada prinsip berikut: 
a. Melampiaskannya melalui cara yang halal dan diizinkan oleh syariat. Misalnya, melampiaskan motivasi seksual dengan cara menikah, sedangkan cara pelampiasan dengan berzina dipandang haram berakibat dosa dan hilang ketenangan. Selain melampiaskan dengan cara yang halal, pemenuhannya juga harus diselaraskan dengan norma sosial dan kebudayaan yang baik. Orang yang belum mampu hendaknya mengendalikannya motivasinya dengan berpuasa agar tetap menjaga kesucian (Taufik, 2006). Allah berfirman: "Dan orang-orang yang tidak mampu menikah hendaklah menjaga kesucian (dirinya), sampai Allah Memberi kemampuan kepada mereka dengan karuniaNya." (QS. An-Nuur: 33). Dan Nabi SAW bersabda; "Wahai sekalian pemuda, barangsiapa di antara kalian yang sudah mampu untuk menikah, maka segeralah menikah, karena nikah akan lebih menundukkan pandangan dan lebih menjaga kehormatan."(HR. Bukhari dan Muslim)

b. Tidak berlebih-lebihan dalam melampiaskan motivasi, karena dapat menimbulkan madharat pada kesehatan fisik dan psikis. Allah melarah dalam firman-Nya “Katakanlah (Muhammad), "Wahai ahli kitab! Janganlah kamu berlebihlebihan dengan cara yang tidak benar dalam agamamu. Dan janganlah kamu mengikuti keinginan orang-orang yang telah tersesat dahulu dan (telah) menyesatkan banyak (manusia), dan mereka sendiri tersesat dari jalan yang lurus." (QS. Al Maidah: 77).

\section{Metode Mempelajari Hal yang Urgen dari Kesehatan Mental}

Yang dimaksud dengan metode mempelajari hal yang urgen dari kesehatan mental yaitu atensi yang besar pada karakter pembentuk insan mulia. Hal ini dilakukan dengan menyelenggarakan pendidikan dan memberikan keteladanan agar setiap individu muslim memiliki tanggung jawab dalam tugas menyebarkan dakwah dan mendirikan sebuah negara Islam. Rasulullah menganjurkan ummatnya untuk memperhatikan kesehatan fisik dengan belajar berkuda, berenang dan memanah yang dianggap dewasa ini sebagai metode terapi kesehatan mental yang tidak diragukan lagi (Najati, 2003). 
Beberapa hal urgen bagi kesehatan mental yang menjadi perhatian Rasulullah dan selalu diajarkan kepada para sahabat antara lain:

1. Perasaan aman, Nabi bersabda: "Barang siapa di antara kalian merasa aman di tengah keluarganya pada pai hari, sehat fisik, dan memiliki bahan makanan hari yang dijalaninya maka seakan-akan selruh dunia menjadi miliknya (HR. Tirmidzi).

2. Bergantung pada diri sendiri, Nabi bersabda: "Siapa yang mau menjamin diriku untuk tidak tidak meminta sesuatu apapun kepada manusia dan aku akan menjamin untuk surga? Tsauban berkata "Akum mau wahai rasul”. Maka terbukti bahwa Tsauban memang tidak pernah meminta sesuatu apa pun kepada orang lain (HR. Abu Dawud).

3. Percaya diri dan teguh pendirian, Nabi bersabda: “Janganlah kalian menjadi pembeo! Kalan akan berkata kami berbaut baik jika orang-orang berbuat baik, dan kami berbuat dzalim jika orang-orang berbuat dzalim. Akan tetapi berpendirianlah kalaian yang teguh! Jika orang berbuat baik, hendaklah kalian berbuat baik, namun jika mereka berbuat buruk, maka janganlah kalian berbuat dzalim (HR. Tirmidzi).

4. Rasa tangggung jawab, Nabi bersabda: "masing-masing kalian adalah pemimpin. Dan masing-masing kalian akan mempertanggung jawabkan apa yang dipimpinnya. Seorang pemimpin mempertanggung jawabkan rakyatnya, seorang suampi merupakn pemimpin dalam keluarganya dan mempertanggungjawabkan apa yang dipimpinnya, seorang istri pemimpin di rumah suaminya dan mempertanggung jawabkan sesuatu yang dipimpinnya. Pelayan merupakan pemimpin dalam harta tuannya dan mempertanggung jawabkan sesuatu yang dipimpinnya (HR. Al Bukhari).

5. Berani mengutarakan pendapat, Nabi bersabda: "Hendakanya salah seorang di antara kalian tidak menghina dirinya sendiri! Para sahabat bertanya "bagaiamana seseorang dari kami menghina dirinya sendiri? Rasulullah menjawab "Dia memandang ada sesuatu yang harus dia katakan karena Allah, namun dia tidak 
mengatakannya. Maka pada hari kiamat Allah Azza Wajalla berfirman "Apa yang menghalangimu untuk mengatakan ini dan itu? Dia pun berkata "aku tidak mengatakannya karena takut pada orang-orang. Allah berfirman "Hanya kepada-Ku kamu lebih berhak untuk merasa takut. (HR. Ibnu Majah)"

6. Ridha menerima takdir, Nabi bersabda: "Ridhalah kamu terhadap apa yang telah diberikan Allah kepadamu, niscaya kamu akan menjadi orang yang paling kaya!" (HR. Ahmad dan Tirmidzi)

7. Sifat Sabar, Nabi bersabda: "Sesungguhnya kadar besarnya balasan tergantung pada kadar besarnyanya cobaan yang ditimpakan, sesungguhnya jika Allah mencintai sebuah kaum maka Allah memberikan cobaan kepada mereka. Barang siapa yang ridha (bersabar) terhadap cobaan maka ia akan memperoleh ridha Allah. Dan barang siapa yang marah maka ia akan mendapat murka Allah (HR. Tirmidzi).

8. Menunaikan pekerjaan secara efektif dan sempurna, Nabi bersabda: "Sesungguhnya Allah menyukai seseorang di antara kalian jika mengerjakan sebuah pekerjaan, maka ia menyempurnakannya (HR. Al Baihaqi).

9. Memperhatikan kesehatan fisik, Nabi bersabda: "Orang mukmin yang kuat lebih baik dan lebih disukai oleh Allah dari pada orang mukmin yang lemah." (HR. Muslim)

Untuk mendidik jiwa dengan sifat-sifat di atas, Rasulullah SAW memberikan kuncinya dengan menjelaskan tentang pentingnya membenahi "sisi dalam" dirinya, yaitu hati. Beliau bersabda: "ketahuilah, sesungguhnya di dalam jasad terdapat sekerat daging, jika sekerat daging itu baik, maka akan baik seluruh jasad. Namun jika sekerat daging itu rusak, maka seluruh jasad akan rusak. Ketahuilah, sekerat daging itu adalah hati.” (HR. Bukhari Muslim).

\section{Penutup}

Dari uraian di atas dapat diambil berberapa kesimpulan antara lain: 1) menjaga kesehatan mental dalam perspektif AlQur'an dan As-Sunnah berpijak pada prinsip wasathiyah (moderasi) dalam pemenuhan kebutuhan antara yang bersifat material dan spiritual, 2) metode Al-Qur'an dan Al Hadits 
dalam merealisasikan kesehatan mental antara lain dengan penguatan dimensi spritual, pengendalian motivasi biologis dan metode mempelajari hal yang urgen bagi kesehatan mental. Ketercapaian metode tersebut dapat dilihat dari kehidupan nabi dan para sahabata dari sisi hubungannya dengan Tuhannya, dengan dirinya sendiri, hubungannya dengan orang lain, dan alam semesta.

\section{Daftar Pustaka}

Ancok, Djamaluddin dan Fuad Nashori Suroso. (1995). Psikologi Islami, Solusi Islam atas Problem Psikologi. Yogyakarta: Pustaka Pelajar.

Daradjat, Zakiah. (1983). Kesehatan Mental. Jakarta: Gunung Agung.

Fahmi, Musthafa. (1977). Kesehatan Jiwa dalam Keluarga, Sekolah dan Masyarakat, terj. Zakiah Daradjat. Jakarta:Bulan Bintang.

Fromm, Erich. (1995). Masyarakat yang Sehat (the Sane Society) terjemah, Thomas Bambang Murtianto. Jakarta: Yayasan Obor Indonesia.

Hawari, Dadang. (1995). Al-Qur'an Ilmu Kedokteran Jiwa dan Kesehatan Jiwa. Yogyakarta: Bina Bhakti Prima Yasa.

Jaelani, A.F. (2000). Penyucian Jiwa (Tazkiyat Al-nafs) \& Kesehatan Mental. Jakarta: Penerbit Amzah.

Langgulung, Hasan. (1986). Teori-Teori Kesehatan Mental. Jakarta: Pustaka al-Husna.

Najati, Utsman, (2003). Psikologi dalam Tinjauan Hadits Nabi., Terj. Wawan Djuanaedi. Jakarta: Penerbit Mustaqim. 
Najati, Utsman. (1987). Al-Qur'an wa Ilmun Nafs. Beirut: Darusy-Syuruq.

Notosoedirjo \& Latipun. (2005). Kesehatan Mental, Konsep dan Penerapan. Malang :UMM Presc.

Salim, Mukhtar, (tth). Sehat Jiwa Raga dengan Shalat. Klaten: Penerbit Wafa Press.

Shihab, M. Quraish. (2003).Wawasan Al-Qur'an: Tafsir Maudhu'i Atas Berbagai Persoalan Umat. Bandung: PT. Mizan Pustaka.

Suharto, Rudhy, (2002), Revolusi Ruhani: Islam dan Kesehatan Jiwa, Jakarta: Pustaka Intermasa, 2002.

Taimiyah, Ibnu. (tth). Majmuu' Fatawa. Saudi Arabia: IsyraarRi’aasatil 'Aammah li Syu'uni Al-Haramain.

Taufik, Muhammad Izudin. (2006). Psikologi Islam. Jakarta: Gema Insani Press.

\section{Dari Internet:}

Febriana Ina, "Dampak Globalisasi terhadap Kesehatan Mental" artikel diambil dari http://inafebriana501.blogspot.co.id/2011/02/sebelumny a-telah-dibahas-tentang.html, akses 20 Juni 2016.

http://www.who.int/features/factfiles/mental_health/en/ akses 20 Juni 2016.

https://id.wikipedia.org/wiki/Monastisisme, tanggal akses 22 Juni 2016). 